Article

\title{
Low-Level Tolerance to Fluoroquinolone Antibiotic Ciprofloxacin in QAC-Adapted Subpopulations of Listeria monocytogenes
}

\author{
Divya Kode ${ }^{1}$, Ramakrishna Nannapaneni ${ }^{1, *}$, Mohit Bansal ${ }^{2}$, Sam Chang ${ }^{1}$, Wen-Hsing Cheng ${ }^{1}$, \\ Chander S. Sharma ${ }^{2}$ and Aaron Kiess ${ }^{2}$ \\ 1 Department of Food Science, Nutrition and Health Promotion, Mississippi State University, Starkville, \\ MS 39762, USA; dsk125@msstate.edu (D.K.); schang@fsnhp.msstate.edu (S.C.); \\ wcheng@fsnhp.msstate.edu (W.-H.C.) \\ 2 Poultry Science Department, Mississippi State University, Starkville, MS 39762, USA; \\ mb3405@msstate.edu (M.B.); csharma@poultry.msstate.edu (C.S.S.); akiess@poultry.msstate.edu (A.K.) \\ * Correspondence: nannapaneni@fsnhp.msstate.edu; Tel.: +1-662-325-7697; Fax: +1-662-325-8728
}

\section{check for} updates

Citation: Kode, D.; Nannapaneni, R.; Bansal, M.; Chang, S.; Cheng, W.-H.; Sharma, C.S.; Kiess, A. Low-Level Tolerance to Fluoroquinolone Antibiotic Ciprofloxacin in QAC-Adapted Subpopulations of Listeria monocytogenes. Microorganisms 2021, 9, 1052. https://doi.org/ 10.3390/microorganisms 9051052

Academic Editor:

Elena Gonzalez-Fandos

Received: 25 April 2021

Accepted: 10 May 2021

Published: 13 May 2021

Publisher's Note: MDPI stays neutra with regard to jurisdictional claims in published maps and institutional affiliations.

Copyright: (c) 2021 by the authors. Licensee MDPI, Basel, Switzerland. This article is an open access article distributed under the terms and conditions of the Creative Commons Attribution (CC BY) license (https:/ / creativecommons.org/licenses/by/ $4.0 /)$.

\begin{abstract}
There was a development of low-level tolerance to fluoroquinolone antibiotic ciprofloxacin in Listeria monocytogenes after sublethal adaptation to quaternary ammonium compound (QAC). Using eight L. monocytogenes strains, we determined the changes in short-range MIC, growth rate, and survival for heterologous stress response to ciprofloxacin, after sublethal exposure to daily cycles of fixed or gradually increasing concentration of QAC. Three main findings were observed. (1) MIC increase-QAC-adapted subpopulations exhibited a significant increase in short-range MIC of ciprofloxacin, by 1.5 to 2.9 fold, as compared to non-adapted control for $4 / 8$ strains $(p<0.05)$. (2) Growth rate increase-QAC-adapted subpopulations exhibited significant 2.1- to 6.8- fold increase in growth rate $\left(\mathrm{OD}_{600}\right.$ at $\left.10 \mathrm{~h}\right)$ in ciprofloxacin-containing broth, as compared to non-adapted control for $5 / 8$ strains $(p<0.05)$. (3) Survival increase-QAC-adapted subpopulations of L. monocytogenes yielded significantly higher survival in ciprofloxacin-containing agar by 2.2 to $4.3 \log \mathrm{CFU} / \mathrm{mL}$ for $4 / 8$ strains, as compared to non-adapted control $(p<0.05)$. However, for other $4 / 8$ strains of L. monocytogenes, there was no increase in survival of QAC-adapted subpopulations, as compared to non-adapted control in ciprofloxacin. These findings suggest the potential formation of low-level ciprofloxacin-tolerant subpopulations in some L. monocytogenes strains when exposed to residual QAC concentrations (where QAC might be used widely) and such cells if not inactivated might create food safety risk.
\end{abstract}

Keywords: Listeria monocytogenes; QAC; sublethal adaptation; biocides; ciprofloxacin; antibiotics

\section{Introduction}

Recent findings indicate that there is a slow emergence of antibiotic resistance in L. monocytogenes. The first antibiotic-resistant L. monocytogenes was isolated in 1988 from a clinical sample in France [1]. About twelve years later in Florida and the Greater Washington DC in 2002-2003, a majority of the 167 isolates of L. monocytogenes obtained from retail foods such as ready-to-eat (RTE) meats, raw chicken carcasses, and fresh produce, were found to be resistant to three antibiotics - ciprofloxacin, tetracycline, and sulfonamide [2]. Then in Italy in 2009, a multidrug-resistant L. monocytogenes was isolated from food and food processing environments, which was resistant against five antibiotics, including, ciprofloxacin, moxifloxacin, linezolid, vancomycin, and trimethoprim/sulfamethoxazole, and with intermediate resistance to clindamycin [3]. Additionally, in Spain, between 1993 and 2006, a significant increase in resistance was reported in L. monocytogenes strains isolated from poultry houses for six antibiotics, including, gentamicin, streptomycin, neomycin, enrofloxacin, ciprofloxacin, and furazolidone [4]. Recently in China, an increase 
in resistance was reported in L. monocytogenes from meat and meat product samples, which exhibited multidrug resistance against five antibiotics, including, tetracycline, penicillin $G$, streptomycin, ampicillin, and cephalothin [5].

Biocides or disinfectants are essential for eliminating or reducing the pathogenic and spoilage microorganisms from food-contact surfaces, equipment, walls, and floors. Although chemical disinfectants are extensively used in the food industry to reduce contaminating microbial load and to maintain hygiene standards, they might fail to eradicate bacteria and could potentially result in bacterial survival. Quaternary ammonium compounds (QACs) are a class of disinfectants that are widely used in the healthcare and food processing industries. QACs are cationic membrane-active agents that interact with the cytoplasmic membrane of the microbial cell, along with intracellular entities like DNA. Their classification is based on the nature of the ' $R$ ' group, which causes structural variations that attribute to their antimicrobial activity and are extremely potent when used at manufacturers' recommended concentrations [6]. Many factors are responsible for reducing QAC efficacy, which then results in sublethal concentrations. The biocidal activity is dependent on temperature, $\mathrm{pH}$, concentration, contact time, and type and load of organic material, and any changes in these parameters significantly affect the bactericidal potency [7]. The presence of organic matter has a significant effect on the efficacy of biocide as it might create a physical hindrance and protect the bacteria against disinfectant action [8]. QACs are biodegradable under aerobic conditions and hence their concentrations in the environment vary considerably [9]. In addition, the application of QACs on wet surfaces dilutes the original lethal concentrations, promoting conditions for sublethal or gradient concentrations [10]. Generally, dilutions occur due to the accumulation of water in places that are assumed to be dry, or in hollow equipment, crevices, cracks, and floors [11].

Despite the frequent cleaning and sanitation sequence, strains of L. monocytogenes are recurrently isolated from food industry premises, such as refrigerated rooms, floors, drains, and equipment, due to the innate ability of this pathogen to adapt to stresses encountered, leading to its continuous persistence [12-15]. Persistent L. monocytogenes strains were frequently isolated from food processing plants that exhibited a low-level resistance to QAC [16]. Several studies also indicate that the use of QACs impose selective pressure, contributing to the emergence of antibiotic-resistant strains. For example, sublethal exposure to progressively increasing concentrations of benzalkonium chloride (a QAC formulation) in L. monocytogenes, resulted in the reduced susceptibility to gentamicin and kanamycin [17]. A tetracycline-resistant L. monocytogenes strain was isolated following a stepwise exposure to a QAC-based disinfectant, didecyl dimethyl ammonium chloride (DDAC) [18]. The persistent strains of L. monocytogenes isolated from pig slaughterhouses exhibited resistance against ampicillin, penicillin, and trimethoprim/sulfamethoxazole [19].

Ciprofloxacin belongs to the fluoroquinolone family of antibiotics, which are extensively used in human medicine. Recently, reduced susceptibility towards fluoroquinolone was reported in L. monocytogenes strains [20]. The derivatives of L. monocytogenes isolated after QAC adaptation showed reduced susceptibility to ciprofloxacin [21]. The exposure to progressively increasing concentrations of QAC resulted in some strains exhibiting increased resistance to ciprofloxacin [22]. Despite these studies, our understanding of the role of QAC and the mechanisms underlying the heterologous stress-response in L. monocytogenes is still limited. Often the methods used for monitoring changes such as minimum inhibitory concentration (MIC) rely on endpoint measurements, and do not take into account the growth kinetics of the microorganism. In the presence of antibiotics, the growth profile of the microorganisms is complex. Therefore, monitoring the growth kinetics is an appropriate tool for determining dynamic bacterial growth patterns in the presence of antibiotics [23]. Therefore, in the present study, we investigated the heterologous stress-response to ciprofloxacin in L. monocytogenes strains, after sublethal adaptation to fixed or gradually increasing concentration of QAC with the following three objectives. (1) Determine the changes in short-range MIC of ciprofloxacin for QAC-adapted subpopulations of L. monocytogenes. (2) Determine the growth kinetics of QAC-adapted 
subpopulations of L. monocytogenes in ciprofloxacin-containing broth model, in comparison to the non-adapted control cells. (3) Determine the survival of QAC-adapted subpopulations of L. monocytogenes in ciprofloxacin-containing agar model versus non-adapted control cells. These findings are useful in understanding the potential link between biocide tolerance and the emergence of fluoroquinolone-resistant strains of L. monocytogenes, in food processing environments that might increase food safety risk.

\section{Materials and Methods}

\subsection{Listeria monocytogenes Strains and Growth Conditions}

L. monocytogenes strains used in this study are listed in Table 1. L. monocytogenes strains were stored at $-20{ }^{\circ} \mathrm{C}$ in Tryptic soy broth containing $0.6 \%$ yeast extract (TSBYE) (BD Bio sciences, San Jose, CA, USA) and were supplemented with $25 \%$ glycerol. The frozen stocks were subcultured on PALCAM agar at $37{ }^{\circ} \mathrm{C}$ for $24 \mathrm{~h}$. To prepare the working stock cultures, a single colony from PALCAM agar was inoculated into $10 \mathrm{~mL}$ TSBYE and incubated at $37^{\circ} \mathrm{C}$ for $18-24 \mathrm{~h}$. Overnight cultures were prepared for each experiment by inoculating a loopful from the working stock into $10 \mathrm{~mL}$ TSBYE kept at $37^{\circ} \mathrm{C}$ for $18-24 \mathrm{~h}$, to reach an inoculum level of approximately $9 \log \mathrm{CFU} / \mathrm{mL}$.

Table 1. L. monocytogenes strains used in this study.

\begin{tabular}{cccccc}
\hline Species & Designation & Lineage & Serotype & Source & Isolation Source \\
\hline L. monocytogenes & N1-227 & I & $4 \mathrm{~b}$ & CDC, Atlanta & Food epidemic \\
\hline L. monocytogenes & ATCC 19116 & III & $4 \mathrm{c}$ & $\begin{array}{c}\text { University of } \\
\text { Wisconsin }\end{array}$ & Poultry \\
\hline L. monocytogenes & ScottA & I & $4 \mathrm{~b}$ & FDA & Human epidemic \\
\hline L. monocytogenes & EGD (Bug600) & II & $1 / 2 \mathrm{a}$ & $\begin{array}{c}\text { Institute } \\
\text { Pasteur }\end{array}$ & Guinea pigs \\
\hline L. monocytogenes & NRRL B-33109 & I & $4 \mathrm{~b}$ & $\begin{array}{c}\text { USDA-ARS, } \\
\text { NADC }\end{array}$ & Cooler condenser \\
\hline L. monocytogenes & NRRL B-33155 & I & $4 \mathrm{~b}$ & $\begin{array}{c}\text { USDA-ARS, } \\
\text { NADC }\end{array}$ & $\begin{array}{c}\text { Sodium caesinate } \\
\text { epidemic strain, } \\
\text { CA, 1985 outbreak }\end{array}$ \\
\hline L. monocytogenes & NRRL B-33157 & I & $4 \mathrm{~b}$ & USDA-ARS, & $\begin{array}{c}\text { Insect debris found } \\
\text { in cheese plant }\end{array}$ \\
\hline L. monocytogenes & ATCC 43257 & I & $4 \mathrm{~b}$ & CDC, Atlanta & $\begin{array}{c}\text { Mexican Style } \\
\text { cheese, CA }\end{array}$ \\
\hline
\end{tabular}

\subsection{Preparation of QAC Solutions}

The 50\% benzalkonium chloride (ACROS Organics ${ }^{\mathrm{TM}}$, Fair Lawn, NJ, USA) was diluted in sterile distilled water to prepare a stock of $5000 \mu \mathrm{g} / \mathrm{mL}$. Then, working stocks of 1 to $8 \mu \mathrm{g} / \mathrm{mL}$ were prepared in TSBYE or in sterile distilled water before each experiment, by diluting the $5000 \mu \mathrm{g} / \mathrm{mL}$ solution.

\subsection{L. monocytogenes Adaptation to Sublethal QAC}

Three methods (two broth models and one water model) were used for the daily cycles of sublethal QAC exposure against planktonic cells of L. monocytogenes in 24-well plates (Techno Plastic Products, AG, Switzerland). (1) A fixed concentration of QAC in the broth model (QAC-P1); (2) a gradually increasing concentration of QAC in broth model (QAC-P2); and (3) a gradually increasing concentration of QAC in distilled water model (QAC-P3). The complete protocols are explained below.

\subsection{Preparation of QAC-Adapted Subpopulation 1 in Broth Model (QAC-P1)}

For QAC-P1, L. monocytogenes strains were exposed to a fixed sublethal concentration of QAC at $2 \mu \mathrm{g} / \mathrm{mL}$ in daily overnight cycles for 5 days in the broth model. In brief, $100 \mu \mathrm{L}$ aliquot of overnight grown cells diluted to $10^{8} \mathrm{CFU} / \mathrm{mL}$ was added to $900 \mu \mathrm{L}$ of TSBYE in 24-microtiter wells, to yield a $1 \mathrm{~mL}$ of $10^{7} \mathrm{CFU} / \mathrm{mL}$ inoculum. Then, $200 \mu \mathrm{L}$ TSBYE containing $4 \mu \mathrm{g} / \mathrm{mL}$ QAC was added at each hourly interval for five hours, to yield a final 
QAC concentration of $2 \mu \mathrm{g} / \mathrm{mL}$ in a final volume of $2 \mathrm{~mL} /$ well for overnight incubation. The 24-well plate was then incubated at room temperature $\left(22^{\circ} \mathrm{C}\right)$ for $19 \mathrm{~h}$ until it reached $10^{9} \mathrm{CFU} / \mathrm{mL}$ or max $\mathrm{OD}_{600}(>0.9)$. The newly QAC- adapted cells were then used to re-run the above daily cycle for 5 days.

\subsection{Preparation of QAC-Adapted Subpopulation 2 in Broth Model (QAC-P2)}

For QAC-P2, L. monocytogenes strains were exposed to a gradually increasing concentration of QAC from $0.5 \mu \mathrm{g} / \mathrm{mL}$ to $4 \mu \mathrm{g} / \mathrm{mL}$, in daily overnight cycles, for 8 days in the broth model. In brief, $100 \mu \mathrm{L}$ aliquot of overnight grown cells diluted to $10^{8} \mathrm{CFU} / \mathrm{mL}$ was added to $900 \mu \mathrm{L}$ of TSBYE in 24-microtiter wells to give rise to a $1 \mathrm{~mL}$ of $10^{7} \mathrm{CFU} / \mathrm{mL}$ inoculum. Then, $200 \mu \mathrm{L}$ TSBYE containing QAC was added at each hourly interval for five hours to yield a final QAC concentration of $0.5 \mu \mathrm{g} / \mathrm{mL}$ (day 1), $1 \mu \mathrm{g} / \mathrm{mL}$ (day 2), $1.5 \mu \mathrm{g} / \mathrm{mL}$ (day 3), $2 \mu \mathrm{g} / \mathrm{mL}$ (day 4), $2.5 \mu \mathrm{g} / \mathrm{mL}$ (day 5), $3 \mu \mathrm{g} / \mathrm{mL}$ (day 6), $3.5 \mu \mathrm{g} / \mathrm{mL}$ (day 7), or $4 \mu \mathrm{g} / \mathrm{mL}$ (day 8 ) in a final volume of $2 \mathrm{~mL} /$ well, before overnight incubation. The 24-well plate was then incubated at room temperature $\left(22^{\circ} \mathrm{C}\right)$ for $19 \mathrm{~h}$ until it reached $10^{9} \mathrm{CFU} / \mathrm{mL}$ or $\mathrm{OD}_{600}$. The newly QAC-adapted cells were then used to re-run the next daily cycle for 8 days, as described above.

\subsection{Preparation of QAC-Adapted Subpopulation 3 in Water Model (QAC-P3)}

For QAC-P3, L. monocytogenes strains were exposed to a gradually increasing concentration from $0.5 \mu \mathrm{g} / \mathrm{mL}$ to $4 \mu \mathrm{g} / \mathrm{mL}$ in daily cycles, for 8 days in the water model. In brief, $100 \mu \mathrm{L}$ aliquot of overnight grown cells diluted in sterile distilled water to $10^{8} \mathrm{CFU} / \mathrm{mL}$ was added to $100 \mu \mathrm{L}$ sterile distilled water containing QAC, to yield a final concentration of $0.5 \mu \mathrm{g} / \mathrm{mL}$ (day 1), $1 \mu \mathrm{g} / \mathrm{mL}$ (day 2), $1.5 \mu \mathrm{g} / \mathrm{mL}$ (day 3), $2 \mu \mathrm{g} / \mathrm{mL}$ (day 4), $2.5 \mu \mathrm{g} / \mathrm{mL}$ (day 5), $3 \mu \mathrm{g} / \mathrm{mL}$ (day 6), $3.5 \mu \mathrm{g} / \mathrm{mL}$ (day 7), or $4 \mu \mathrm{g} / \mathrm{mL}$ (day 8 ), for $1 \mathrm{~h}$, and then supplemented with $1.8 \mathrm{~mL}$ of TSBYE containing $0.5 \mu \mathrm{g} / \mathrm{mL}$ QAC, to yield a final volume of $2 \mathrm{~mL} /$ well before overnight incubation. The 24 -well plate was then incubated at room temperature $\left(22{ }^{\circ} \mathrm{C}\right.$ ) for $23 \mathrm{~h}$ until it reached $10^{9} \mathrm{CFU} / \mathrm{mL}$ or $\mathrm{OD}_{600}$. The new QAC-adapted cells were then used to re-run the next daily cycle for 8 days, as described above.

\subsection{Preparation of Ciprofloxacin Solutions}

The stock solution of ciprofloxacin (Ciprofloxacin, 98\%, ACROS Organics ${ }^{\mathrm{TM}}$, Fair Lawn, NJ, USA) at $500 \mu \mathrm{g} / \mathrm{mL}$ was prepared in sterilized distilled water and stored at $4^{\circ} \mathrm{C}$ for 2 weeks. Prior to each experiment, working stock solutions of 1 to $10 \mu \mathrm{g} / \mathrm{mL}$ were prepared in TSBYE from the $500 \mu \mathrm{g} / \mathrm{mL}$ stock.

2.8. Determination of Short-Range MIC of Ciprofloxacin for QAC-Adapted Subpopulations and Non-Adapted Control of L. monocytogenes Strains

The changes in susceptibilities of QAC-adapted subpopulations and non-adapted control of L. monocytogenes strains against ciprofloxacin were determined using the shortrange minimum inhibitory concentration (MIC) method described previously [10], with slight modifications. The ciprofloxacin concentrations in the range of 1 to $10 \mu \mathrm{g} / \mathrm{mL}$ with $1 \mu \mathrm{g} / \mathrm{mL}$ increments were tested in the short-range MIC. The overnight grown QACadapted subpopulations and non-adapted control were diluted to $10^{7} \mathrm{CFU} / \mathrm{mL}$ in TSBYE and an aliquot of $30 \mu \mathrm{L}$ was inoculated into individual wells of a 96-well microtiter plate containing $270 \mu \mathrm{L}$ of ciprofloxacin concentrations range, such that the resulting final inoculum concentration in the wells was $10^{6} \mathrm{CFU} / \mathrm{mL}$. The MIC was defined as the lowest concentration of ciprofloxacin preventing the growth, after incubation at $37{ }^{\circ} \mathrm{C}$ for $48 \mathrm{~h}$. Optical density at $600 \mathrm{~nm}\left(\mathrm{OD}_{600}\right)$ was recorded after $48 \mathrm{~h}$.

2.9. Determination of Growth Kinetics of QAC-Adapted Subpopulations and Non-Adapted Control of L. monocytogenes Strains in Ciprofloxacin-Containing Broth

Growth kinetics of QAC-adapted subpopulations and non-adapted control of L. monocytogenes strains were evaluated in the presence of sublethal concentrations of ciprofloxacin in TSBYE. The overnight grown QAC-adapted and non-adapted control cells $\left(10^{9} \mathrm{CFU} / \mathrm{mL}\right)$ 
were diluted to $10^{7} \mathrm{CFU} / \mathrm{mL}$ in TSBYE. The growth response of L. monocytogenes strains was monitored in TSBYE containing $2 \mu \mathrm{g} / \mathrm{mL}$ ciprofloxacin concentration. In brief, $30 \mu \mathrm{L}$ aliquot of $10^{7} \mathrm{CFU} / \mathrm{mL}$ was added to $270 \mu \mathrm{L}$ of TSBYE containing $2 \mu \mathrm{g} / \mathrm{mL}$ ciprofloxacin in a $96-w e l l$ polystyrene plate, and incubated at $37^{\circ} \mathrm{C}$ in a shaker at $150 \mathrm{rpm}$ (C24 Classic series incubator shaker, New Brunswick Scientific Inc., Edison, NJ). Growth was monitored by recording $\mathrm{OD}_{600}$ at every $4 \mathrm{~h}$ for up to $24 \mathrm{~h}$ (ELx800 Absorbance Microplate Reader, BioTek Instruments, Inc., Winooski, VT, USA).

2.10. Determination of Survival of QAC-Adapted Subpopulations and Non-Adapted Control of L. monocytogenes Strains in Ciprofloxacin-Containing Agar

The survival of QAC-adapted subpopulations and non-adapted control of L. monocytogenes strains were determined on Tryptic soy agar containing $0.6 \%$ yeast extract (TSAYE) supplemented with $2 \mu \mathrm{g} / \mathrm{mL}$ ciprofloxacin. In brief, overnight grown QAC-adapted and non-adapted cells of L. monocytogenes strains were diluted to $10^{7} \mathrm{CFU} / \mathrm{mL}$. Subsequently, four decimal dilutions were performed and $50 \mu \mathrm{L}$ of each dilution was spotted twice on TSAYE containing ciprofloxacin and TSAYE without ciprofloxacin (control plate). The plates were incubated at $37^{\circ} \mathrm{C}$ to determine CFU counts after $48 \mathrm{~h}$.

\subsection{Statistical Analysis}

A completely randomized design with a $2 \times 3$ factorial structure (adapted cells and non-adapted control cells vs. three QAC-adapted subpopulations) in a randomized complete block design, with replication considered as a block. The ciprofloxacin MIC between QAC-adapted subpopulations and non-adapted control were compared using the unpaired two-tailed $t$-test at three significance levels $(p<0.05 ; p<0.01$; and $p<0.001)$ using Microsoft Excel (Microsoft Excel, Version 2008). The lag phase duration at $\mathrm{OD}_{600}$ between QAC-adapted subpopulations and non-adapted control were compared using the unpaired two-tailed $t$-test at three significance levels $(p<0.05 ; p<0.01$; and $p<0.001)$, using Microsoft Excel (Microsoft Excel, Version 2008). The fold increase and percentage increase in ciprofloxacin MIC and fold increase in growth rate was tested by Duncan's multiple range test $(p<0.05)$ using the SAS software (SAS 9.4 TS Level 1M5; SAS Institute Inc., Cary, NC, USA). Statistical analysis was performed using one-way ANOVA at a significance level of $p<0.05$. Bacterial counts from each replicate were log-transformed in Microsoft excel before statistical analysis. Counts for survival were analyzed using one-way ANOVA in a completely randomized block design and the means were separated by Fisher's protected LSD when $p<0.05$ using the SAS software (SAS 9.4 TS Level 1M5; SAS Institute Inc., Cary, NC, USA).

\section{Results}

3.1. Changes in Short-Range MIC of Ciprofloxacin for QAC-Adapted Subpopulations of L. monocytogenes

Figure 1 shows the changes in short-range MIC of ciprofloxacin for eight L. monocytogenes strains before and after sublethal exposure to daily cycles of fixed QAC concentration in broth model (QAC-P1), or gradually increasing QAC concentration in broth model (QAC-P2), or gradually increasing QAC concentration in water model (QAC-P3). Table 2 shows the fold increase in short-range MIC of three QAC-adapted subpopulations versus non-adapted control for eight $L$. monocytogenes strains.

Before sublethal QAC exposure, L. monocytogenes strains exhibited MICs in the range of 2.3 to $6.0 \mu \mathrm{g} / \mathrm{mL}$ ciprofloxacin. After sublethal QAC exposure, the short-range MIC of ciprofloxacin for all strains of L. monocytogenes increased significantly to the range of 5.7 to $8.0 \mu \mathrm{g} / \mathrm{mL}$ for QAC-P1, 4.0 to $8.0 \mu \mathrm{g} / \mathrm{mL}$ for QAC-P2, and 4.3 to $7.7 \mu \mathrm{g} / \mathrm{mL}$ for QAC-P3 (Figure 1). This increase in the short-range MIC of ciprofloxacin by 2.6 to $3.3 \mu \mathrm{g} / \mathrm{mL}$ of QAC-P1, or 2.0 to $4.3 \mu \mathrm{g} / \mathrm{mL}$ of QAC-P2, or 2.3 to $3.7 \mu \mathrm{g} / \mathrm{mL}$ of QAC-P3 was found to be significant $(p<0.01$ or $p<0.05$ ) for $4 / 8$ L. monocytogenes strains, as compared to non-adapted control (Figure 1C,E-G). Additionally, for these $4 / 8$ L. monocytogenes strains (ScottA, NRRL B 33155, NRRL B 33157, and ATCC 43257), this change in short-range 
ciprofloxacin MIC was equivalent to 1.6 to 2.6 fold (=60-157\%) higher for QAC-P1, or 1.5 to 2.9 fold $(=46-186 \%)$ higher for QAC-P2, or 1.5 to 2.6 fold $(=54-157 \%)$ higher for QAC-P3, as a result of the QAC sublethal exposure, which was significant as compared to non-adapted control $(p<0.05)$. On the other end, for $1 / 8$ L. monocytogenes strains (ATCC 19116), there was a 1.2 to 1.4 fold $(=16-35 \%)$ higher in short-range MIC of ciprofloxacin for QAC-P1 or QAC-P2 or QAC-P3 (Table 2).

\section{Narrow-range MIC of ciprofloxacin}

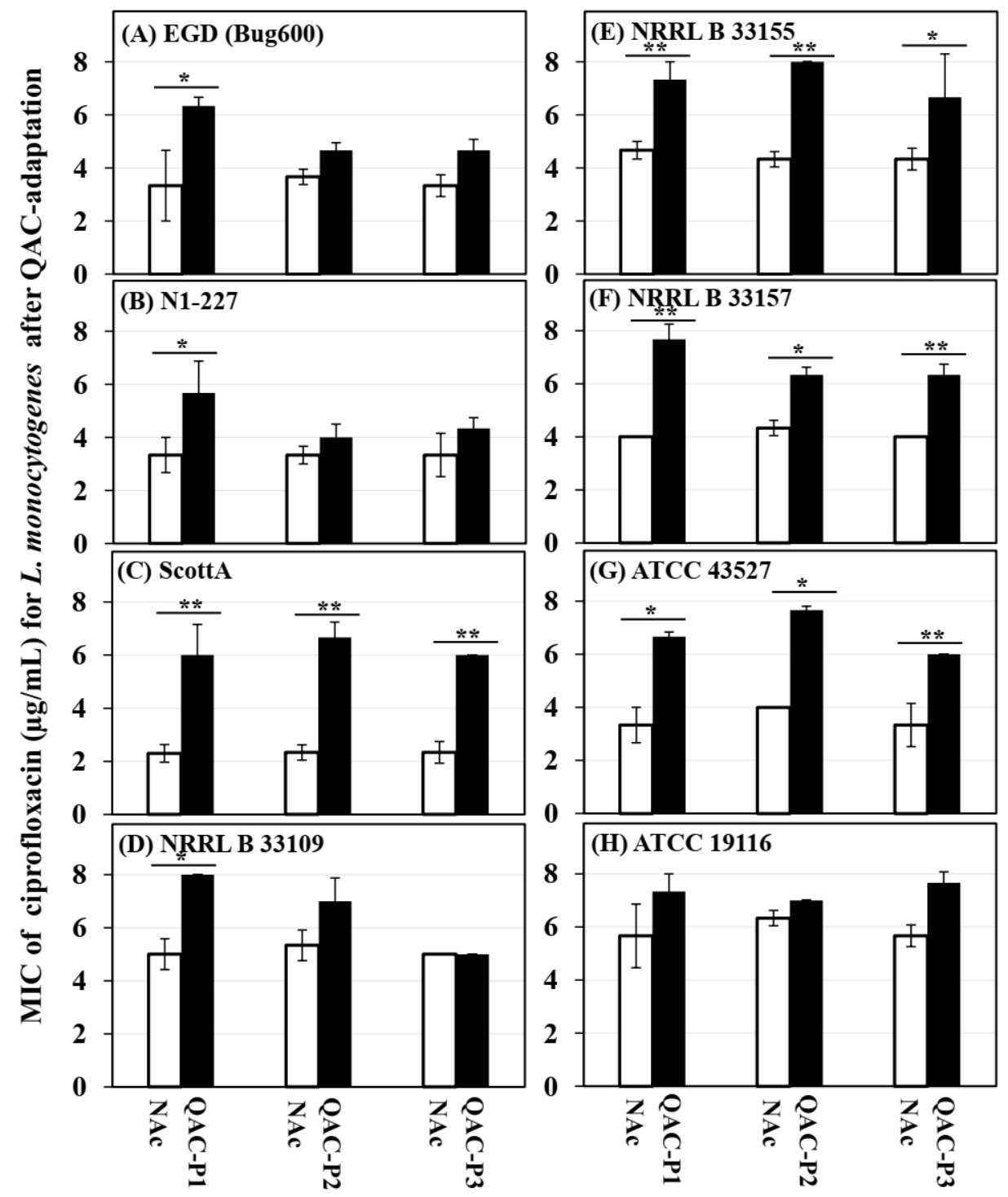

Figure 1. Changes in narrow-range MIC of ciprofloxacin $(\mu \mathrm{g} / \mathrm{mL})$ for three QAC-adapted subpopulations (closed bars) compared to non-adapted controls (NAc, open bars) of eight L. monocytogenes strains (A-H). Error bars indicate standard errors of means. Statistically significant $p$ values are indicated by asterisks ( $p<0.05$; ${ }^{* *} p<0.01$;) that were obtained using the unpaired two-tailed $t$-test.

There were significant strain $\times$ subpopulation interactions in the short-range MIC of ciprofloxacin for some L. monocytogenes strains. For example, QAC-P1 of strain EGD showed a 1.9 fold increase (=90\% higher), as compared to QAC-P2/QAC-P2 with a 1.3 to 1.4 fold increase (=17-40\% higher) in the short-range MIC of ciprofloxacin, in comparison to the non-adapted controls. ScottA exhibited the highest fold increase of 2.6 to 2.9 (=157-186\% higher) in MIC of ciprofloxacin for QAC-P1, QAC-P2, and QAC-P3, as compared to the non-adapted control (Table 2). 
Table 2. Fold increase in MIC of ciprofloxacin, fold increase in growth rate ( $\mathrm{OD}_{600}$ in ciprofloxacin-containing broth), and percent increase in survival (in ciprofloxacin-containing agar) of three QAC-adapted subpopulations (QAC-P1, QAC-P2, and QAC-P3), compared to non-adapted control of eight L. monocytogenes strains.

\begin{tabular}{|c|c|c|c|c|c|c|}
\hline \multirow[t]{2}{*}{$\begin{array}{c}\text { Listeria monocytogenes } \\
\text { Strains }\end{array}$} & \multirow{2}{*}{$\begin{array}{l}\text { Fold Increase }{ }^{1} \text { in MIC } \\
\text { of Ciprofloxacin for } \\
\text { QAC-P1 } \pm \text { SE }\end{array}$} & \multicolumn{4}{|c|}{$\begin{array}{l}\text { Fold Increase }{ }^{2} \text { in Growth }\left(\mathrm{OD}_{600}\right) \text { of QAC-P1 Compared to } \\
\text { Non-Adapted Control in Ciprofloxacin-Containing Broth at Different } \\
\text { Time Points }\end{array}$} & \multirow{2}{*}{$\begin{array}{c}\text { Percentage Increase }{ }^{3} \text { in } \\
\text { Survivals in } \\
\text { Ciprofloxacin-Agar for } \\
\text { QAC-P1 } \pm \text { SE }\end{array}$} \\
\hline & & $10 \mathrm{~h}$ & $12 \mathrm{~h}$ & $20 \mathrm{~h}$ & $24 \mathrm{~h}$ & \\
\hline EGD (Bug600) & $1.9 \pm 0.2^{\mathrm{a}}$ & $4.5 \pm 0.8^{a}$ & $5.3 \pm 1.0^{\mathrm{a}}$ & $2.4 \pm 0.4^{\mathrm{a}}$ & $1.9 \pm 0.4^{\mathrm{b}}$ & $58.3 \pm 5.4^{\mathrm{a}}$ \\
\hline N1 227 & $1.7 \pm 0.3^{b}$ & $1.0 \pm 0.0^{\mathrm{c}}$ & $0.9 \pm 0.0^{b}$ & $2.4 \pm 0.5^{\mathrm{a}}$ & $4.0 \pm 0.2^{\mathrm{a}}$ & $5.77 \pm 0.5^{c}$ \\
\hline Scott A & $2.6 \pm 0.3^{a}$ & $4.0 \pm 0.2^{\mathrm{a}}$ & $4.8 \pm 0.2^{\mathrm{a}}$ & $3.1 \pm 0.9^{\mathrm{a}}$ & $2.2 \pm 1.0^{\mathrm{a}}$ & $1.75 \pm 2.7^{c}$ \\
\hline NRRL B 33109 & $1.6 \pm 0.2^{b}$ & $1.4 \pm 0.4^{\mathrm{b}}$ & $1.4 \pm 0.5^{\mathrm{b}}$ & $1.2 \pm 0.3^{b}$ & $1.1 \pm 0.1^{\mathrm{d}}$ & $1.20 \pm 0.3^{c}$ \\
\hline NRRL B 33155 & $1.6 \pm 0.2^{b}$ & $3.9 \pm 0.7^{\mathrm{a}}$ & $3.4 \pm 1.3^{\mathrm{a}}$ & $2.3 \pm 1.1^{a}$ & $1.5 \pm 0.2^{c}$ & $46.4 \pm 1.7^{\mathrm{a}}$ \\
\hline NRRL B 33157 & $1.9 \pm 0.1^{\mathrm{a}}$ & $3.6 \pm 0.4^{a}$ & $4.3 \pm 0.8^{a}$ & $1.0 \pm 0.1^{b}$ & $1.0 \pm 0.1^{\mathrm{d}}$ & $36.7 \pm 13.6^{b}$ \\
\hline ATCC 43257 & $2.0 \pm 0.4^{\mathrm{a}}$ & $5.0 \pm 1.1^{a}$ & $5.9 \pm 0.2^{\mathrm{a}}$ & $2.5 \pm 0.4^{\mathrm{a}}$ & $2.2 \pm 0.4^{b}$ & $55.6 \pm 10.6^{\mathrm{a}}$ \\
\hline ATCC 19116 & $1.3 \pm 0.1^{b}$ & $1.1 \pm 0.3^{c}$ & $1.1 \pm 0.2^{b}$ & $1.2 \pm 0.0^{\mathrm{b}}$ & $1.1 \pm 0.1^{\mathrm{d}}$ & $0.80 \pm 0.4^{\mathrm{c}}$ \\
\hline \multirow[t]{2}{*}{$\begin{array}{l}\text { Listeria monocytogenes } \\
\text { Strains }\end{array}$} & \multirow{2}{*}{$\begin{array}{l}\text { Fold Increase }{ }^{1} \text { in MIC } \\
\text { of Ciprofloxacin for } \\
\text { QAC-P2 } \pm \text { SE }\end{array}$} & \multicolumn{4}{|c|}{$\begin{array}{l}\text { Fold Increase }{ }^{2} \text { in Growth }\left(\mathrm{OD}_{600}\right) \text { of QAC-P2 Compared to } \\
\text { Non-Adapted Control in Ciprofloxacin-Containing Broth at Different } \\
\text { Time Points }\end{array}$} & \multirow{2}{*}{$\begin{array}{l}\text { Percentage Increase }{ }^{3} \text { in } \\
\text { Survivals in } \\
\text { Ciprofloxacin-Agar for } \\
\text { QAC-P2 } \pm \text { SE }\end{array}$} \\
\hline & & $10 \mathrm{~h}$ & $12 \mathrm{~h}$ & $20 \mathrm{~h}$ & $24 \mathrm{~h}$ & \\
\hline EGD (Bug600) & $1.3 \pm 0.1^{\mathrm{c}}$ & $4.9 \pm 0.9^{\mathrm{a}}$ & $5.6 \pm 1.0^{\mathrm{a}}$ & $5.1 \pm 0.4^{\mathrm{a}}$ & $2.1 \pm 0.4^{\mathrm{a}}$ & $46.8 \pm 4.1^{\mathrm{b}}$ \\
\hline N1 227 & $1.2 \pm 0.3^{c}$ & $1.0 \pm 0.0^{b}$ & $1.0 \pm 0.0^{c}$ & $1.0 \pm 0.5^{\mathrm{b}}$ & $1.3 \pm 0.2^{\mathrm{a}}$ & $-4.6 \pm 2.3^{\mathrm{d}}$ \\
\hline Scott A & $2.9 \pm 0.1^{\mathrm{a}}$ & $5.1 \pm 0.2^{\mathrm{a}}$ & $5.6 \pm 0.2^{\mathrm{a}}$ & $3.7 \pm 0.9^{\mathrm{a}}$ & $1.6 \pm 1.0^{\mathrm{a}}$ & $60.3 \pm 2.6^{\mathrm{a}}$ \\
\hline NRRL B 33109 & $1.3 \pm 0.0^{c}$ & $0.9 \pm 0.4^{b}$ & $0.8 \pm 0.5^{c}$ & $0.9 \pm 0.3^{b}$ & $1.0 \pm 0.1^{\mathrm{b}}$ & $0.90 \pm 0.8^{c}$ \\
\hline NRRL B 33155 & $1.8 \pm 0.1^{\mathrm{b}}$ & $3.3 \pm 0.7^{\mathrm{a}}$ & $2.6 \pm 1.3^{b}$ & $2.0 \pm 1.1^{\mathrm{a}}$ & $1.2 \pm 0.2^{\mathrm{a}}$ & $49.8 \pm 7.1^{b}$ \\
\hline NRRL B 33157 & $1.5 \pm 0.0^{\mathrm{b}}$ & $6.8 \pm 0.4^{\mathrm{a}}$ & $5.7 \pm 0.8^{a}$ & $2.2 \pm 0.1^{\mathrm{a}}$ & $1.2 \pm 0.1^{\mathrm{a}}$ & $58.9 \pm 3.9^{\mathrm{a}}$ \\
\hline ATCC 43257 & $1.9 \pm 0.1^{b}$ & $6.7 \pm 1.1^{\mathrm{a}}$ & $5.1 \pm 0.2^{\mathrm{a}}$ & $3.1 \pm 0.4^{\mathrm{a}}$ & $2.1 \pm 0.4^{\mathrm{a}}$ & $59.7 \pm 4.2^{\mathrm{a}}$ \\
\hline ATCC 19116 & $1.2 \pm 0.1^{c}$ & $1.1 \pm 0.3^{b}$ & $1.0 \pm 0.2^{\mathrm{c}}$ & $1.0 \pm 0.0^{\mathrm{b}}$ & $1.0 \pm 0.1^{\mathrm{b}}$ & $2.85 \pm 1.7^{\mathrm{c}}$ \\
\hline \multirow[t]{2}{*}{$\begin{array}{l}\text { Listeria monocytogenes } \\
\text { Strains }\end{array}$} & \multirow{2}{*}{$\begin{array}{l}\text { Fold Increase }{ }^{1} \text { in MIC } \\
\text { of Ciprofloxacin for } \\
\text { QAC-P3 } \pm \text { SE }\end{array}$} & \multicolumn{4}{|c|}{$\begin{array}{l}\text { Fold Increase }{ }^{2} \text { in Growth }\left(\mathrm{OD}_{600}\right) \text { of QAC-P3 Compared to } \\
\text { Non-Adapted Control in Ciprofloxacin-Containing Broth at Different } \\
\text { Time Points }\end{array}$} & \multirow{2}{*}{$\begin{array}{l}\text { Percentage Increase }{ }^{3} \text { in } \\
\text { Survivals in } \\
\text { Ciprofloxacin-Agar for } \\
\text { QAC-P3 } \pm \text { SE }\end{array}$} \\
\hline & & $10 \mathrm{~h}$ & $12 \mathrm{~h}$ & $20 \mathrm{~h}$ & $24 \mathrm{~h}$ & \\
\hline EGD (Bug600) & $1.4 \pm 0.1^{\mathrm{b}}$ & $2.1 \pm 0.6^{b}$ & $3.1 \pm 1.1^{\mathrm{b}}$ & $3.4 \pm 0.7^{\mathrm{a}}$ & $2.3 \pm 1.0^{\mathrm{a}}$ & $48.1 \pm 1.9^{a}$ \\
\hline N1 227 & $1.3 \pm 0.3^{b}$ & $0.8 \pm 0.2^{c}$ & $1.2 \pm 0.4^{c}$ & $1.3 \pm 0.4^{b}$ & $1.2 \pm 0.1^{b}$ & $3.3 \pm 5.4^{\mathrm{d}}$ \\
\hline Scott A & $2.6 \pm 0.3^{a}$ & $1.2 \pm 0.2^{c}$ & $1.8 \pm 0.6^{c}$ & $2.0 \pm 0.3^{a}$ & $1.2 \pm 0.3^{b}$ & $22.6 \pm 6.8^{c}$ \\
\hline NRRL B 33109 & $1.0 \pm 0.0^{c}$ & $1.1 \pm 0.8^{c}$ & $0.8 \pm 1.7^{c}$ & $1.2 \pm 1.5^{b}$ & $1.1 \pm 0.4^{b}$ & $0.41 \pm 1.3^{\mathrm{d}}$ \\
\hline NRRL B 33155 & $1.5 \pm 0.3^{\mathrm{a}}$ & $1.7 \pm 1.0^{\mathrm{c}}$ & $2.2 \pm 1.5^{\mathrm{b}}$ & $1.6 \pm 1.4^{\mathrm{a}}$ & $1.2 \pm 0.1^{\mathrm{b}}$ & $52.1 \pm 5.0^{\mathrm{a}}$ \\
\hline NRRL B 33157 & $1.6 \pm 0.1^{b}$ & $5.1 \pm 0.7^{\mathrm{a}}$ & $5.2 \pm 0.7^{\mathrm{a}}$ & $1.3 \pm 1.4^{b}$ & $1.0 \pm 0.0^{\mathrm{b}}$ & $57.3 \pm 7.5^{a}$ \\
\hline ATCC 43257 & $1.8 \pm 0.5^{\mathrm{a}}$ & $6.4 \pm 0.7^{\mathrm{a}}$ & $6.6 \pm 0.6^{a}$ & $3.5 \pm 1.0^{\mathrm{a}}$ & $1.9 \pm 0.2^{\mathrm{a}}$ & $33.1 \pm 17.6^{b}$ \\
\hline ATCC 19116 & $1.4 \pm 0.1^{b}$ & $1.3 \pm 2.5^{c}$ & $1.1 \pm 2.5^{\mathrm{c}}$ & $0.9 \pm 0.2^{b}$ & $0.9 \pm 0.1^{b}$ & $3.24 \pm 1.1^{\mathrm{d}}$ \\
\hline
\end{tabular}

Different letter indicate significant differences $(p<0.05)$ by Duncan's multiple range test. for ${ }^{1}$ Fold Increase in MIC of Ciprofloxacin for QAC-Adapted Subpopulations, or ${ }^{2}$ Fold Increase in Growth (OD600) of QAC-Adapted Subpopulations Compared to Non-Adapted Control in Ciprofloxacin-Containing Broth at Different Time Points, or ${ }^{3}$ Percentage Increase in Survivals in Ciprofloxacin-Agar for QAC-Adapted Subpopulations.

\subsection{Changes in the Growth Rate of QAC-Adapted Subpopulations of L. monocytogenes in Ciprofloxacin-Containing Broth}

The growth curves $\left(\mathrm{OD}_{600}\right)$ of eight L. monocytogenes strains in ciprofloxacin before and after sublethal exposure to fixed or gradually increasing concentration of QAC are shown in the Supplementary Figure S1 for QAC-P1, in Supplementary Figure S2 for QAC-P2, and in Supplementary Figure S3 for QAC-P3. Figure 2 shows the changes in lag phase duration, and Figure 3 shows the increase in growth rate at $10 \mathrm{~h}$ for three QAC-adapted subpopulations versus non-adapted control for eight L. monocytogenes strains. Table 2 shows the fold changes in growth rate at different time-points for three QAC-adapted subpopulations versus the non-adapted control for eight L. monocytogenes strains. 
Ciprofloxacin-containing broth $(2 \mu \mathrm{g} / \mathrm{mL})$

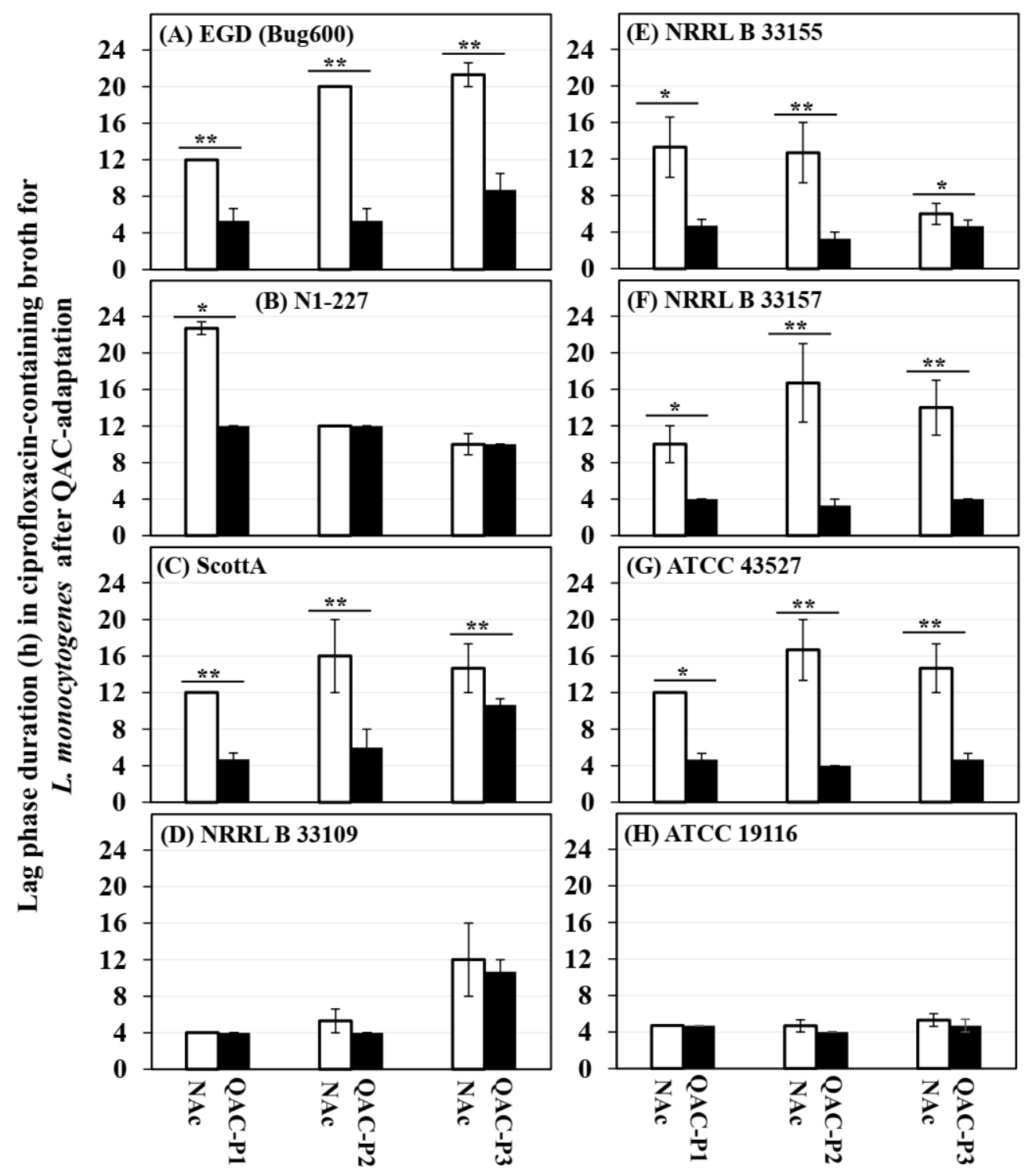

Figure 2. Changes in the lag phase duration (h) for the three QAC-adapted subpopulations (closed bars) in ciprofloxacin-containing broth $(2 \mu \mathrm{g} / \mathrm{mL}$ ) as compared to the non-adapted controls (NAc, open bars) of eight L. monocytogenes strains $(\mathbf{A}-\mathbf{H})$ at $37^{\circ} \mathrm{C}$. Error bars indicate the standard errors of means. Statistically significant $p$-values are indicated by asterisks $\left({ }^{*} p<0.05 ;{ }^{* *} p<0.01\right.$; ) that were obtained using the unpaired two-tailed $t$-test.

For 5/8 L. monocytogenes strains (EGD, ScottA, NRRL B 33155, NRRL B 33157, and ATCC 43527), there was a significant decrease in the lag phase down to 4-5.3 $\mathrm{h}$ for QAC-P1 (Supplementary Figure S1A,C,E-G), 3.3-6 h for QAC-P2 (Supplementary Figure S2A,C,E$\mathrm{G}$ ), or 4-10.7 h for QAC-P3 (Supplementary Figure S3A,C,E-G), as compared to a longer lag phase of $10-21 \mathrm{~h}$ for the non-adapted control in ciprofloxacin-containing broth $(p<0.05)$ (Figure 2A,C,E-G). For these 5/8 strains of L. monocytogenes, a significant increase in growth rate $\left(\mathrm{OD}_{600}\right)$ of QAC-P1, QAC-P2, and QAC-P3 was observed in ciprofloxacin-containing broth at the 10-h time-point (Figure 3), which was 3.6 to 5.0 fold higher for QAC-P1, 3.3 to 6.8 fold higher for QAC-P2, or 1.2 to 6.4 fold higher for QAC-P3 versus the non-adapted control $(p<0.05)$ (Table 2$)$. Such an increase in growth rate also continued for the QACadapted subpopulations to the 12 -h time-point for these $5 / 8$ strains in ciprofloxacin. With few exceptions, the highest increase in growth rate in ciprofloxacin was for the QACadapted subpopulations of strain ATCC 43527 or NRRL B 33157 (serotype 4b), followed by 
EGD (serotype 1/2a) at the 10- or 12-h time-point. At the 20-h time-point in ciprofloxacin, the growth rate of QAC-P1 or QAC-P2 or QAC-P3 for 3/8 L. monocytogenes strains (EGD, ScottA, and ATCC 43257) continued to be 2.0 to 5.1 fold higher, as compared to the nonadapted control. At the 24-h time-point, there was a continued 2.1- to 2.3-fold higher growth rate for the QAC-P2/QAC-P3 for 1/8 strains of L. monocytogenes (EGD) in ciprofloxacin (Table 2).

Ciprofloxacin-containing broth $(2 \mu \mathrm{g} / \mathrm{mL})$
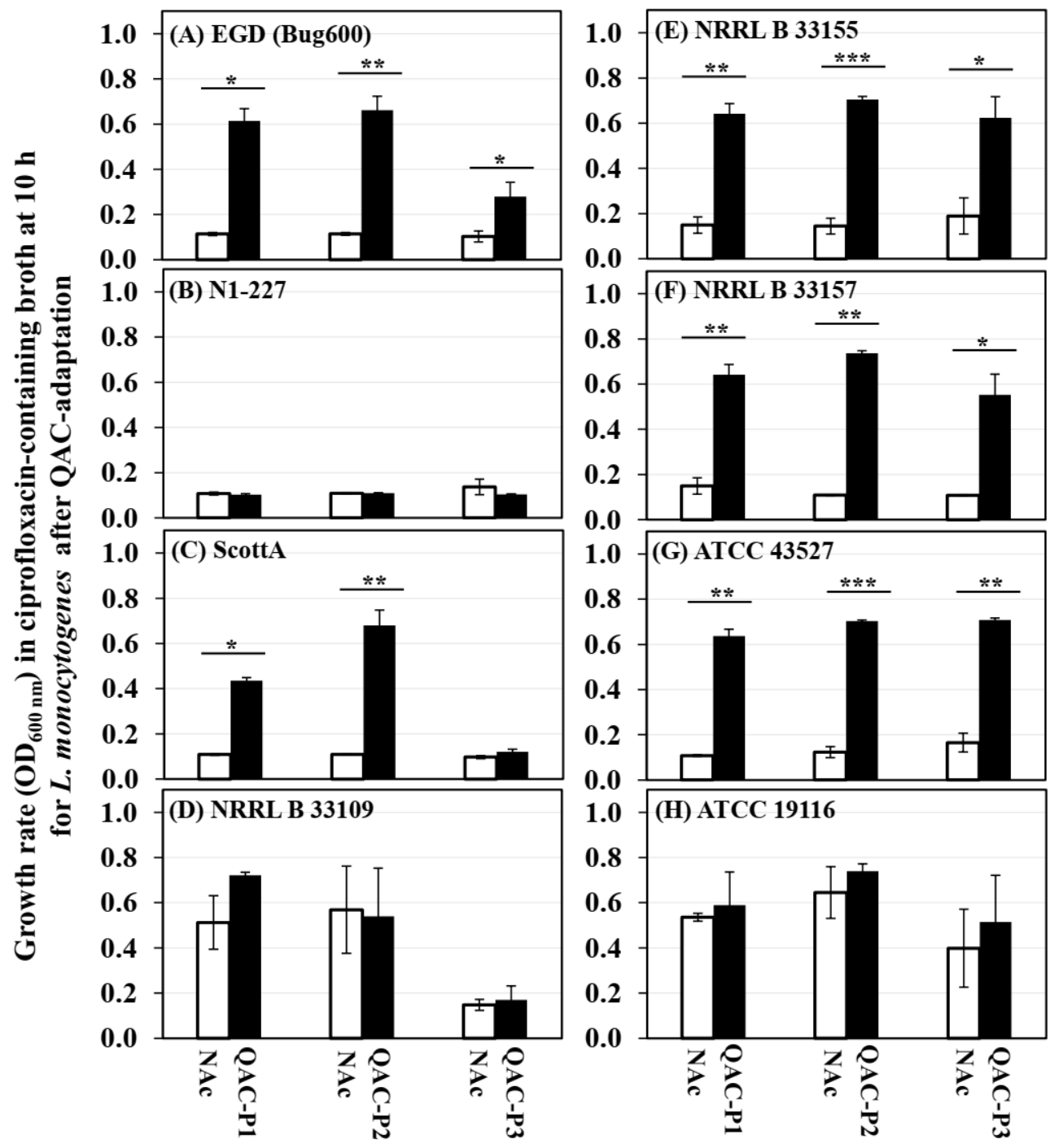

Figure 3. Changes in growth rate $\left(\mathrm{OD}_{600}\right)$ for three QAC-adapted subpopulations (closed bars) in the ciprofloxacin-containing broth $(2 \mu \mathrm{g} / \mathrm{mL})$ at $10 \mathrm{~h}$, as compared to the non-adapted control (NAc, open bars) of eight $L$. monocytogenes strains $(\mathbf{A}-\mathbf{H})$ at $37^{\circ} \mathrm{C}$. Error bars indicate the standard errors of means. Statistically significant $p$-values are indicated by the asterisks $\left({ }^{*} p<0.05\right.$; ${ }^{* *} p<0.01$; *** $p<0.001$ ) that were obtained using the unpaired two-tailed $t$-test.

There were some significant strain $\times$ subpopulation interactions for an increase in L. monocytogenes growth rate in ciprofloxacin. For example, QAC-P1 of N1-227 had 4.0-fold increase in growth rate in ciprofloxacin, as compared to a 1.2- to 1.3-fold increase for QAC-P2 or QAC-P3 (Table 2).

\subsection{Changes in the Survival of QAC-Adapted Subpopulations of L. monocytogenes in Ciprofloxacin-Containing Agar}

Figure 4 shows the changes in survival $(\log \mathrm{CFU} / \mathrm{mL})$ in the ciprofloxacin-containing agar model $(2 \mu \mathrm{g} / \mathrm{mL}$ ciprofloxacin in TSAYE) for eight $L$. monocytogenes strains, before 
and after sublethal exposure to a fixed or gradually increasing concentration of QAC. Table 2 shows the fold changes in survival of three QAC-adapted subpopulations versus the non-adapted control for eight $L$. monocytogenes strains.

Ciprofloxacin-containing agar $(2 \mu \mathrm{g} / \mathrm{mL})$
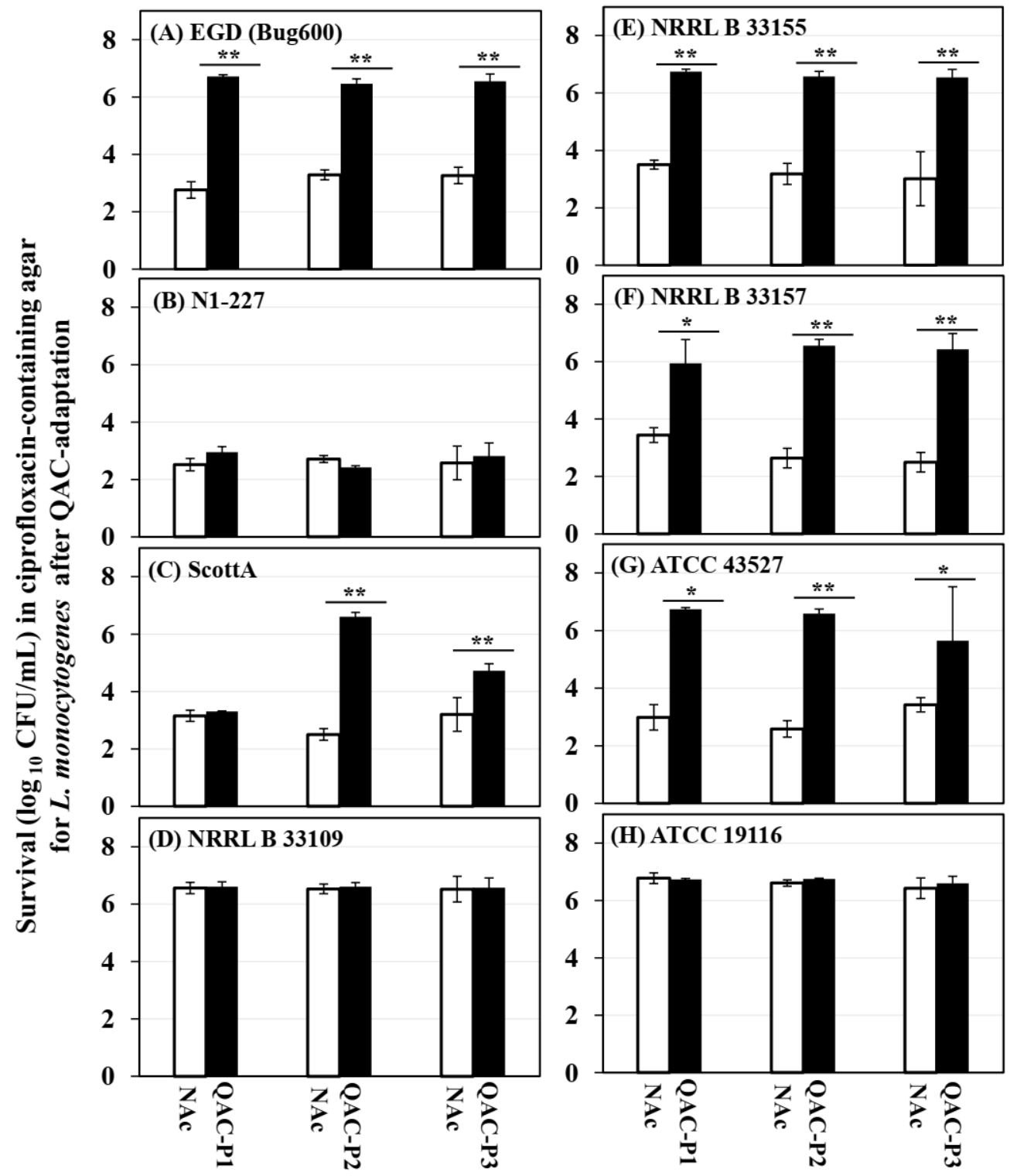

Figure 4. Changes in survival $\left(\log _{10} \mathrm{CFU} / \mathrm{mL}\right)$ for three QAC-adapted subpopulations (closed bars) in ciprofloxacin-containing agar $(2 \mu \mathrm{g} / \mathrm{mL}$ ) as compared to the non-adapted control (NAc, open bars) of eight $L$. monocytogenes strains $(\mathbf{A}-\mathbf{H})$. Error bars indicate the standard errors of means. Statistically significant $p$-values are indicated by asterisks $\left({ }^{*} p<0.05 ;{ }^{* *} p<0.01\right.$; ) that were obtained using the unpaired two-tailed $t$-test.

Two patterns were observed for changes in survival in ciprofloxacin-containing agar. (1) QAC-adapted subpopulations of the 4/8 L. monocytogenes strains (EGD, NRRL B 33155, NRRL B 33157, ATCC 43527) exhibited the highest increase in survival in ciprofloxacin, which was by 2.5 to $4.0 \log \mathrm{CFU} / \mathrm{mL}$ for QAC-P1, by 3.2 to $4.1 \log$ CFU/mL for QAC-P2, or by 2.2 to $4.0 \log$ CFU/mL for QAC-P3 $(p<0.05)$, as compared to the non-adapted control (Figure $4 \mathrm{~A}, \mathrm{E}-\mathrm{G}$ ). This was equivalent to a percent increase in survival by 36.7 to $58.3 \mathrm{~S} \%$ for QAC-P1, or by 46.8 to $60.3 \%$ QAC-P2, or by 33.1 to $57.3 \%$ QAC-P3 in ciprofloxacin, as compared to the non-adapted control for these $4 / 8$ strains (Table 2). In this group, the QAC-adapted subpopulations of NRRL B 33157 
(serotype 4b) followed by EGD (serotype 1/2a) exhibited the highest survival increase in ciprofloxacin with some exceptions. (2) In contrast, QAC-adapted subpopulations of the 3/8 L. monocytogenes strains (N1-227, NRRL 33109 and ATCC 19116) showed no significant change in survival in ciprofloxacin, as compared to the non-adapted control.

With few exceptions within the six strains belonging to serotype $4 \mathrm{~b}$, QAC-adapted subpopulation NRRL B 33157 exhibited the highest percent increase in survival in ciprofloxacin, followed by serotype 1/2a (EGD), while that of serotype 4c (ATCC 19116) did not differ from the non-adapted control (Figure 4).

There were some significant strain $\times$ subpopulation interactions for an increase in survival in ciprofloxacin for 1/8 L. monocytogenes strains. For example, QAC-P2 of ScottA exhibited the highest percent survival increase in ciprofloxacin, as compared to QAC-P1 or QAC-P3.

When the ciprofloxacin level increased from $2 \mu \mathrm{g} / \mathrm{mL}$ to $4 \mu \mathrm{g} / \mathrm{mL}$ in agar, all QACadapted subpopulations were non-detectable for all eight strains of L. monocytogenes, similar to that of the non-adapted control (data not shown).

\section{Discussion}

The objective of this study was to evaluate the influence of sublethal concentrations of biocide QAC in inducing heterologous stress-response to fluoroquinolone antibiotic ciprofloxacin in L. monocytogenes, under controlled laboratory conditions. In the food processing environments, even though sanitizers and disinfectants were routinely used at 50-100 times greater than that of their minimum bactericidal concentration (MBC) to kill foodborne bacterial pathogens, planktonic cells or biofilms that might be present in the crevices might be frequently exposed to lower or sublethal concentrations of biocides because of dilution caused by the wetness on those surfaces or by interactions with food residues. Cleaning and disinfection steps might also leave residues of sanitizers or disinfectants, which might expose bacterial cells to a gradient of concentrations in the processing environments. Recent findings showed that such gradual exposure to sublethal concentrations of biocides could co-select for bacterial cells that were tolerant to lethal concentrations of biocides [10] or might cross-protect against antibiotics [24]. Therefore, it is important to understand the role of sublethal concentrations of biocides in the emergence of heterologous stress-response in L. monocytogenes, which might lead to antibiotic tolerance/resistance development.

We tested three approaches for creating the continuous exposure to sublethal concentrations of QAC against actively growing planktonic cells of L. monocytogenes and evaluated the subsequent changes in antibiotic susceptibility against ciprofloxacin by three different methods-(1) detecting the changes in short-range MIC of QAC-adapted subpopulations; (2) detecting the changes in the growth rate of QAC-adapted subpopulations in the ciprofloxacin-containing broth model; and (3) detecting the changes in survival of the QACadapted subpopulations in the ciprofloxacin-containing agar model. Our results showed that there was a potential for the development of low-level tolerance to ciprofloxacin in the L. monocytogenes strains after continuous sublethal exposure to QAC. A significant increase in the short-range MIC of the QAC-adapted subpopulations was observed to be about 1.5- to 2.9-fold for 4 out of 8 L. monocytogenes strains used in this study. A similar lowlevel 2-4 fold increase in MIC of ciprofloxacin was observed in L. monocytogenes after step-wise exposure to an increasing concentration of QAC, where 11 ciprofloxacin-sensitive strains with an initial MIC of $1 \mu \mathrm{g} / \mathrm{mL}$, exhibited a 2-fold increase in MIC to $2 \mu \mathrm{g} / \mathrm{mL}$ of ciprofloxacin, after QAC adaptation [22]. While five other ciprofloxacin-sensitive L. monocytogenes strains with an MIC of $1 \mu \mathrm{g} / \mathrm{mL}$ exhibited a 4-fold increase in ciprofloxacin $\mathrm{MIC}$ to $4 \mu \mathrm{g} / \mathrm{mL}$ after QAC adaptation. In these and our study, the highest MIC increase of ciprofloxacin against QAC-adapted subpopulations of L. monocytogenes strains never exceeded beyond $8 \mu \mathrm{g} / \mathrm{mL}$ of ciprofloxacin. In other studies, a 4 -fold increase in MIC of ciprofloxacin to $32 \mu \mathrm{g} / \mathrm{mL}$ against some L. monocytogenes strains was observed for the cells adapted to QAC [21]. A recent publication by Guerin et al., 2021 reported similar 
findings in which, repeated exposure to sublethal BC and DDAC resulted in a lower susceptibility to ciprofloxacin in 14 and 21 L. monocytogenes strains, respectively. BC exposed L. monocytogenes strains exhibited a 2.6-fold increase in MIC of ciprofloxacin from $2.1 \mu \mathrm{g} / \mathrm{mL}$ for control to $5.48 \mu \mathrm{g} / \mathrm{mL}$ in the adapted strains. DDAC-exposed cells exhibited a 4.5 -fold increase in MIC from $2.1 \mu \mathrm{g} / \mathrm{mL}$ for the control to $9.48 \mu \mathrm{g} / \mathrm{mL}$ in the adapted strains. Additionally, these strains continued to exhibit reduced susceptibility to ciprofloxacin after the de-adaptation step [25]. Other pathogens such as Pseudomonas aeruginosa, which was enriched for 33 generations in QAC, demonstrated as high as 256-fold increase in MIC of ciprofloxacin [26].

While the increase in the short-range MIC of the QAC-adapted subpopulations of L. monocytogenes was statistically significant, these changes in the QAC-adapted subpopulations were below the standard breakpoints for ciprofloxacin. However, such increases in the short-range MIC of ciprofloxacin against QAC-adapted subpopulations of L. monocytogenes that were non-detectable by the standard MIC method should not be ignored, since the subpopulations of adapted cells were likely to be present to allow for faster growth rate under prolonged selective pressure. Eventually, such low-level MIC changes might potentially lead to a broader or high-level antibiotic resistance against ciprofloxacin [27]. MIC is an offline measurement tool that monitors the end-point results but is not intended for determining the microbial response continuously. Since a small increase in MIC remains usually undetected by the standard MIC [28], we employed growth kinetics to determine the dynamic effect of ciprofloxacin on the adapted cells of L. monocytogenes. QAC-adapted subpopulations of L. monocytogenes exhibited a significantly shorter lag phase and a faster growth rate in the presence of ciprofloxacin-containing broth. Similar findings with other bacteria led to understanding the role of the lag phase in the development of antibiotic tolerance. In general, the lag phase protects the bacteria from antibiotics, causing delayed or extended growth [29]. Such kinetic growth assays monitoring the duration of lag phases is an indicator of dose-dependent antibiotic inhibition [23]. The decrease in lag phase shown is an early sign of the competitive advantage of the adapted subpopulation over the non-tolerant subpopulation. By employing $1 / 2 \mathrm{MIC}(2 \mu \mathrm{g} / \mathrm{mL})$ of ciprofloxacin in broth, we observed the growth dynamics in the logarithmic phase of the adapted subpopulation over the non-adapted control. When ciprofloxacin concentration in broth increases or is equal to that of the MIC concentration, the growth dynamics of the adapted and non-adapted extend and takes longer. The two non-adapted strains (ATCC 19116 and NRRL-B-33109) that exhibited higher than $5 \mu \mathrm{g} / \mathrm{mL}$ of ciprofloxacin MIC were unaffected by this comparison and might require a much higher threshold concentration. Numerous factors affect the tolerance in bacteria, however, changes in the lag time were considered to be the first step towards the development of antibiotic tolerance. While we did not study the effect of higher concentration of ciprofloxacin in broth in decreasing the lag phase of the QAC-adapted subpopulations, the extension of any lag phase in the presence of lethal concentrations of antibiotics might actually prevent the killing of bacteria [30]. It appears that the kinetic growth curves of the QAC-adapted subpopulations of L. monocytogenes observed in our study indicate the possible presence of the subpopulations of actively growing adapted cells, in the presence of ciprofloxacin-containing broth.

Therefore, to separate the subpopulations of adapted cells versus non-adapted cells, the actively growing planktonic cells of the QAC-adapted subpopulations of L. monocytogenes were plated on the ciprofloxacin-containing agar model. A significant increase in survival of the QAC-adapted subpopulations of L. monocytogenes was observed in the presence of ciprofloxacin-containing agar. In general, the QACadapted subpopulations yielded about 2 to $4 \log$ CFU / mL higher loads on ciprofloxacincontaining agar, as compared to the non-adapted cells for 4 out of the 8 strains tested. The representative individual colonies isolated on the ciprofloxacin-containing agar for the QAC-adapted subpopulations of L. monocytogenes need further study through whole-genome analysis. 
Our results showed that, conversely to the other L. monocytogenes strains, the ciprofloxacin susceptibility of two strains ATCC 19116 and NRRL B-33109 was never altered by the different sublethal exposures to QAC in any subpopulation (QAC-P1, QAC-P2, or QAC-P3). We did not observe any increase in the short-range MIC, any increase in growth rate, and any increase in survival of the QAC-adapted subpopulations of these two strains, as compared to their non-adapted controls. This indicates that there might be two possibilities at work-(1) there might be a strain-specific response in QAC-adapted subpopulations of L. monocytogenes in the development of low-level tolerance against ciprofloxacin; and (2) there is an inability of some strains to adapt under certain conditions, perhaps requiring a longer exposure and higher sublethal shocks. By comparing their genomes with those of other strains that are able to adapt, it would be interesting to understand why both these strains did not adapt to QAC under some conditions. This would inform the physiological and genetic pathways that are potentially involved in adaptation to QAC and fluoroquinolone cross-resistance development in different L. monocytogenes strains.

Generally, in L. monocytogenes, the cross-resistance between antibiotics and QAC is linked to active efflux or due to acquisition of transferable genetic materials [17]. Resistance to fluoroquinolone is multifactorial and can be via one or a combination of target-site gene mutations, increased production of multidrug-resistance (MDR) efflux pumps, modifying enzymes, or target-protection proteins. The overexpression of regulatory genes that control the expression of native efflux pumps localized in the bacterial membrane such as $m d r L$ and lde genes occurred only in the BAC-resistant strains [31]. L. monocytogenes strains harboring these genes or strains that are intrinsically or adaptively tolerant to biocides have a higher growth advantage over the ones that lack these parameters [32]. The efflux pumps $l d e$ and $m d r L$ are responsible for demonstrating an increased tolerance to QAC and ciprofloxacin. The lde gene encodes for a multi-drug efflux pump, which was associated with fluoroquinolone resistance and was previously described in some strains of L. monocytogenes [33]. In a future study, we will explore if the expression of these efflux pump regulatory gene expression influence the low-level tolerance to ciprofloxacin in the QAC-adapted subpopulations of L. monocytogenes observed in this study.

Our continuing work will explore the following four aspects. (1) Using a pool of naturally occurring strains, we will compare the resistance level to ciprofloxacin L. monocytogenes and their corresponding level of resistance to QAC. (2) Using at least one strain of L. monocytogenes, we will perform WGS sequencing before and after adaptation to QAC and the selected gene expression associated with cross-tolerance to QAC and ciprofloxacin. (3) The stability of the acquired QAC-induced cross-tolerance to ciprofloxacin in the subpopulations of L. monocytogenes. (4) It would also be interesting to understand the correlation between both homologous and heterologous tolerance response in L. monocytogenes after QAC adaptation, with respect to ciprofloxacin and other selected antibiotics.

In conclusion, our findings show the potential for the development of low-level tolerance to fluoroquinolone antibiotic ciprofloxacin in QAC-adapted subpopulations of some L. monocytogenes strains that resulted in a significant increase in short-range MIC, growth rate, and survival in broth/agar models. Although we did not observe the development of higher level tolerance/resistance to ciprofloxacin in QAC-adapted subpopulations of L. monocytogenes in these eight strains tested, such low-level responses might have survival advantage in the gradual emergence of antibiotic-resistant subpopulations. Therefore, the early detection of low-level tolerance to antibiotics is vital, because such phenotypic variants might serve as a stepping-stone towards clinical antibiotic resistance development in the environmentally persisting stress-adapted L. monocytogenes strains, if subjected to cycles of sublethal exposure to QAC or other biocides in various environments.

Supplementary Materials: The following are available online at https:/ /www.mdpi.com/article/10 $.3390 /$ microorganisms9051052/s1. Figure S1. Changes in growth curves $\left(\mathrm{OD}_{600}\right)$ of QAC-P1 (open squares) in ciprofloxacin-containing broth $(2 \mu \mathrm{g} / \mathrm{mL})$ compared to non-adapted control (open circles) 
of eight L. monocytogenes strains at $37^{\circ} \mathrm{C}$. Error bars indicate standard error of means, Figure S2. Changes in growth curves $\left(\mathrm{OD}_{600}\right)$ of QAC-P2 (open squares) in ciprofloxacin-containing broth $(2 \mu \mathrm{g} / \mathrm{mL})$ compared to non-adapted control (open circles) of eight L. monocytogenes strains at $37^{\circ} \mathrm{C}$. Error bars indicate standard error of means, Figure S3. Changes in growth curves $\left(\mathrm{OD}_{600}\right)$ of QAC-P3 (open squares) in ciprofloxacin-containing broth $(2 \mu \mathrm{g} / \mathrm{mL}$ ) compared to non-adapted control (open circles) of eight L. monocytogenes strains at $37^{\circ} \mathrm{C}$. Error bars indicate standard error of means.

Author Contributions: Conceptualization, R.N.; methodology, R.N. and D.K.; software, D.K.; validation, D.K. and R.N.; formal analysis, D.K. and M.B.; investigation, D.K. and R.N.; resources, S.C.; data curation, D.K.; writing-original draft preparation, D.K. and R.N.; writing-review and editing, R.N. and A.K.; visualization, R.N. and D.K.; supervision, R.N.; project administration, R.N. and W.-H.C.; funding acquisition, R.N. and C.S.S. All authors have read and agreed to the published version of the manuscript.

Funding: This material is based upon the work that is supported by the National Institute of Food and Agriculture, U.S. Department of Agriculture for the project MIS-401180 under award number 2016-69003-24600 and by the Food Safety Initiative award to Nannapaneni from the Mississippi Agricultural and Forestry Experiment Station under project MIS-401210 with grant number USDAARS SCA No. 58-6402-2729.

Institutional Review Board Statement: Not applicable.

Informed Consent Statement: Not applicable.

Data Availability Statement: All relevant data are within the paper.

Conflicts of Interest: The authors declare no conflict of interest.

\section{References}

1. Poyart-Salmeron, C.; Carlier, C.; Trieu-Cuot, P.; Courvalin, P.; Courtieu, A.-L. Transferable plasmid-mediated antibiotic resistance in Listeria monocytogenes. Lancet 1990, 335, 1422-1426. [CrossRef]

2. Zhang, Y.; Yeh, E.; Hall, G.; Cripe, J.; Bhagwat, A.A.; Meng, J. Characterization of Listeria monocytogenes isolated from retail foods. Int. J. Food Microbiol. 2007, 113, 47-53. [CrossRef]

3. Conter, M.; Paludi, D.; Zanardi, E.; Ghidini, S.; Vergara, A.; Ianieri, A. Characterization of antimicrobial resistance of foodborne Listeria monocytogenes. Int. J. Food Microbiol. 2009, 128, 497-500. [CrossRef]

4. Alonso-Hernando, A.; Prieto, M.; García-Fernández, C.; Alonso-Calleja, C.; Capita, R. Increase over time in the prevalence of multiple antibiotic resistance among isolates of Listeria monocytogenes from poultry in Spain. Food Control 2012, $23,37-41$. [CrossRef]

5. Chen, M.; Cheng, J.; Zhang, J.; Chen, Y.; Zeng, H.; Xue, L.; Lei, T.; Pang, R.; Wu, S.; Wu, H.; et al. Isolation, potential virulence, and population diversity of Listeria monocytogenes from meat and meat products in China. Front. Microbiol. 2019, 10, 1-10. [CrossRef]

6. Gerba, C.P. Quaternary ammonium biocides: Efficacy in application. Appl. Environ. Microbiol. 2015, 81, 464-469. [CrossRef]

7. Bashor, M.P.; Curtis, P.A.; Keener, K.M.; Sheldon, B.W.; Kathariou, S.; Osborne, J.A. Effects of Carcass Washers on Campylobacter Contamination in Large Broiler Processing Plants. Poult. Sci. 2004, 83, 1232-1239. [CrossRef]

8. Iñiguez-Moreno, M.; Avila-Novoa, M.G.; Gutiérrez-Lomelí, M. Resistance of pathogenic and spoilage microorganisms to disinfectants in the presence of organic matter and their residual effect on stainless steel and polypropylene. J. Glob. Antimicrob. Resist. 2018, 14, 197-201. [CrossRef]

9. Tezel, U.; Pavlostathis, S.G. Quaternary ammonium disinfectants: Microbial adaptation, degradation and ecology. Curr. Opin. Biotechnol. 2015, 33, 296-304. [CrossRef]

10. Møretrø, T.; Schirmer, B.C.T.; Heir, E.; Fagerlund, A.; Hjemli, P.; Langsrud, S. Tolerance to quaternary ammonium compound disinfectants may enhance growth of Listeria monocytogenes in the food industry. Int. J. Food Microbiol. 2017, 241, $215-224$. [CrossRef]

11. Cerf, O.; Carpentier, B.; Sanders, P. Tests for determining in-use concentrations of antibiotics and disinfectants are based on entirely different concepts: "Resistance" has different meanings. Int. J. Food Microbiol. 2010, 136, 247-254. [CrossRef]

12. Aase, B.; Sundheim, G.; Langsrud, S.; Rorvik, L.M. Occurrence of and a possible mechanism for resistance to a quaternary ammonium compound in Listeria monocytogenes. Int. J. Food Microbiol. 2000, 62, 57-63. [CrossRef]

13. Carpentier, B.; Cerf, O. Review-Persistence of Listeria monocytogenes in food industry equipment and premises. Int. J. Food Microbiol. 2011, 145, 1-8. [CrossRef]

14. Ferreira, V.; Wiedmann, M.; Teixeira, P.; Stasiewicz, M.J. Listeria monocytogenes Persistence in Food-Associated Environments: Epidemiology, Strain Characteristics, and Implications for Public Health. J. Food Prot. 2014, 77, 150-170. [CrossRef]

15. Fox, E.M.; Leonard, N.; Jordan, K. Physiological and Transcriptional Characterization of Persistent and Nonpersistent Listeria monocytogenes Isolates. Appl. Environ. Microbiol. 2011, 77, 6559-6569. [CrossRef] 
16. Ortiz, S.; Lopez, V.; Martinez-Suarez, J.V. Control of Listeria monocytogenes contamination in an Iberian pork processing plant and selection of benzalkonium chloride-resistant strains. Food Microbiol. 2014, 39, 81-88. [CrossRef]

17. Romanova, N.A.; Wolffs, P.F.G.; Brovko, L.Y.; Griffiths, M.W. Role of Efflux Pumps in Adaptation and Resistance of Listeria monocytogenes to Benzalkonium Chloride Role of Efflux Pumps in Adaptation and Resistance of Listeria monocytogenes to Benzalkonium Chloride. Appl. Environ. Microbiol. 2006, 72, 3498-3503. [CrossRef]

18. Soumet, C.; Méheust, D.; Pissavin, C.; Le Grandois, P.; Frémaux, B.; Feurer, C.; Le Roux, A.; Denis, M.; Maris, P. Reduced susceptibilities to biocides and resistance to antibiotics in food-associated bacteria following exposure to quaternary ammonium compounds. J. Appl. Microbiol. 2016, 121, 1275-1281. [CrossRef]

19. Sereno, M.J.; Viana, C.; Pegoraro, K.; da Silva, D.A.L.; Yamatogi, R.S.; Nero, L.A.; Bersot, L. dos S. Distribution, adhesion, virulence and antibiotic resistance of persistent Listeria monocytogenes in a pig slaughterhouse in Brazil. Food Microbiol. 2019, 84, 103234. [CrossRef]

20. Morvan, A.; Moubareck, C.; Leclercq, A.; Hervé-Bazin, M.; Bremont, S.; Lecuit, M.; Courvalin, P.; Le Monnier, A. Antimicrobial resistance of Listeria monocytogenes strains isolated from humans in France. Antimicrob. Agents Chemother. 2010, 54, 2728-2731. [CrossRef]

21. Rakic-Martinez, M.; Drevets, D.A.; Dutta, V.; Katic, V.; Kathariou, S. Listeria monocytogenes strains selected on ciprofloxacin or the disinfectant benzalkonium chloride exhibit reduced susceptibility to ciprofloxacin, gentamicin, benzalkonium chloride, and other toxic compounds. Appl. Environ. Microbiol. 2011, 77, 8714-8721. [CrossRef]

22. Yu, T.; Jiang, X.; Zhang, Y.; Ji, S.; Gao, W.; Shi, L. Effect of Benzalkonium Chloride adaptation on sensitivity to antimicrobial agents and tolerance to environmental stresses in Listeria monocytogenes. Front. Microbiol. 2018, 9. [CrossRef]

23. Theophel, K.; Schacht, V.J.; Schlüter, M.; Schnell, S.; Stingu, C.-S.; Schaumann, R.; Bunge, M. The importance of growth kinetic analysis in determining bacterial susceptibility against antibiotics and silver nanoparticles. Front. Microbiol. 2014, 5, 544. [CrossRef]

24. Wales, A.; Davies, R. Co-Selection of Resistance to Antibiotics, Biocides and Heavy Metals, and Its Relevance to Foodborne Pathogens. Antibiotics 2015, 4, 567-604. [CrossRef]

25. Guérin, A.; Bridier, A.; Le Grandois, P.; Sévellec, Y.; Palma, F.; Félix, B.; Roussel, S.; Soumet, C.; Karpíšková, R.; Pomelio, F.; et al. Exposure to quaternary ammonium compounds selects resistance to ciprofloxacin in Listeria monocytogenes. Pathogens 2021, 10, 220. [CrossRef]

26. Mc Cay, P.H.; Ocampo-Sosa, A.A.; Fleming, G.T.A. Effect of subinhibitory concentrations of benzalkonium chloride on the competitiveness of Pseudomonas aeruginosa grown in continuous culture. Microbiology 2010, 156, 30-38. [CrossRef]

27. Ching, C.; Zaman, M.H. Development and selection of low-level multi-drug resistance over an extended range of sub-inhibitory ciprofloxacin concentrations in Escherichia coli. Sci. Rep. 2020, 10, 1-9. [CrossRef]

28. Goldstein, F. The potential clinical impact of low-level antibiotic resistance in Staphylococcus aureus. J. Antimicrob. Chemother. 2007, 59, 1-4. [CrossRef]

29. Li, B.; Qiu, Y.; Shi, H.; Yin, H. The importance of lag time extension in determining bacterial resistance to antibiotics. Analyst 2016, 141, 3059-3067. [CrossRef]

30. Fridman, O.; Goldberg, A.; Ronin, I.; Shoresh, N.; Balaban, N.Q. Optimization of lag time underlies antibiotic tolerance in evolved bacterial populations. Nature 2014, 513, 418-421. [CrossRef]

31. Tamburro, M.; Ripabelli, G.; Vitullo, M.; Dallman, T.J.; Pontello, M.; Amar, C.F.L.; Sammarco, M.L. Gene expression in Listeria monocytogenes exposed to sublethal concentration of benzalkonium chloride. Comp. Immunol. Microbiol. Infect. Dis. 2015, 40, 31-39. [CrossRef] [PubMed]

32. Alonso-Hernando, A.; Capita, R.; Prieto, M.; Alonso-Calleja, C. Comparison of antibiotic resistance patterns in Listeria monocytogenes and Salmonella enterica strains pre-exposed and exposed to poultry decontaminants. Food Control 2009, 20, 1108-1111. [CrossRef]

33. Godreuil, S.; Galimand, M.; Gerbaud, G.; Jacquet, C.; Courvalin, P. Efflux pump Lde is associated with fluoroquinolone resistance in Listeria monocytogenes. Antimicrob. Agents Chemother. 2003, 47, 704-708. [CrossRef] [PubMed] 